\title{
Paleoenvironment interpretation of a 1760 years B.P. old sediment in a mangrove area of the Bay of Guanabara, using pollen analysis
}

\author{
ORTRUD M. BARTH ${ }^{1,2}$, LUIZ E.U. SÃO-THIAGO ${ }^{2}$ and MARCIA A. BARROS ${ }^{2}$ \\ ${ }^{1}$ Laboratório de Ultra-estrutura Viral, Departamento de Virologia, Instituto Oswaldo Cruz \\ Fiocruz, Avenida Brasil 4365, 21040-000 Rio de Janeiro, RJ, Brasil \\ ${ }^{2}$ Laboratório de Palinologia, Departamento de Geologia, Instituto de Geociências \\ Universidade Federal do Rio de Janeiro, CCMN, J2-19, Ilha do Fundão \\ 21949-900 Rio de Janeiro, RJ, Brasil \\ Manuscript received on May 16, 2005; accepted for publication on October 5, 2005; \\ presented by LUCIA MENDONÇA PREVIATO
}

\begin{abstract}
A sediment sample was obtained at $122 \mathrm{~cm}$ from the top of a drilling core in the Guapimirim mangrove, Bay of Guanabara, and analyzed using pollen analysis. This muddy core reached a sandy ground at $133 \mathrm{~cm}$. ${ }^{14} \mathrm{C}$ datation got the age of $1760 \pm 50$ years B.P. The most frequent pollen grains were mangrove species of Rhizophora mangle, Laguncularia racemosa and Avicennia schaueriana. "Restinga" and tropical rain forest vegetation was recognized behind the mangrove. After the last sea transgression at 2500 years B.P., the water level lowered to its actual size, allowing the installation of this mangrove.
\end{abstract}

Key words: pollen, paleoenvironment, mangrove, Bay of Guanabara, Rio de Janeiro, 1760 B.P.

\section{INTRODUCTION}

Mangroves are ecological systems spread around the globe in tropical coastal areas submitted to daily variations of water salinity and sea level oscillations. Plants and animals that live in these areas have developed characteristics of adaptation and are strongly specialized to survive in extreme environmental conditions.

There are today only few areas covered with mangrove vegetation in the surroundings of the Bay of Guanabara (Figure 1). The great cities of Rio de Janeiro, Niterói and São Gonçalo have requested regions around the bay where formerly the tropical rain forest (Mata Atlântica) competed with the mangroves. Open areas, like savannas, were not com-

Correspondence to: Ortrud M. Barth

E-mail: barth@ioc.fiocruz.br mon earlier (Amador 1997, Barth et al. 2004). The human impact on this ecosystem started by the time of colonization at 1500 A.D., and strongly increased during the last two centuries.

The AEP (area of environment protection) of Guapimirim is one of the few well-preserved mangrove patches. It is located at the northeast side of the Bay of Guanabara, between $22^{\circ} 40^{\prime}-22^{\circ} 46^{\prime} \mathrm{S}$ and $42^{\circ} 57^{\prime}-43^{\circ} 07^{\prime} \mathrm{W}$, comprising circa of $14,000 \mathrm{ha}$.

The dimension of the Bay of Guanabara changed during the Holocene. After the last great ice age, its largest extension was reached around 8,000 years B.P. (Amador 1997) during the major sea transgression. The bay occupied large areas that today are free of water, and human settlements in the Guanabara region started with the deposition of the oldest known "sambaquís" (Kneip 2001, C.S.F. 


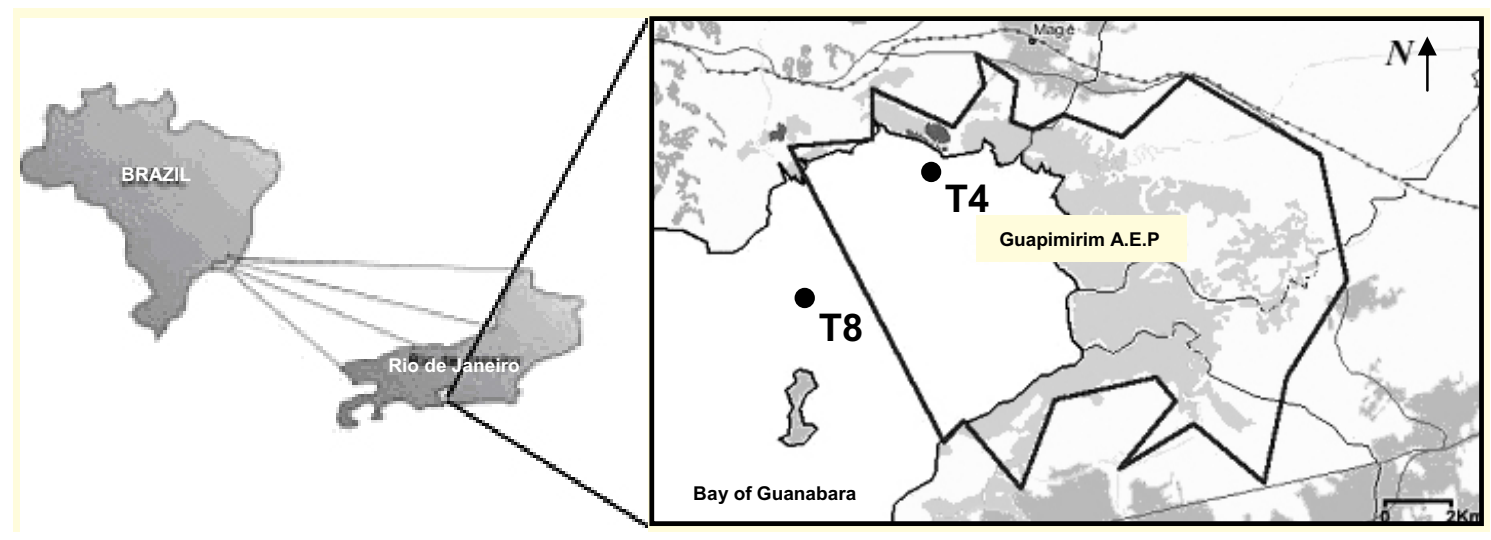

Fig. 1 - Localization of cores T4 (•) and T8 (x) in the Bay of Guanabara.

Senna, unpublished data). This means amounts of shells, bones, coal and ceramics, in places where the natives lived beside (beside where the natives lived?). One believes that mangroves were not well installed in the surroundings of the bay at this time. In sequence, the sea level got lower, attaining the minimum at circa 4,200 years B.P. (Amador 1997, Barth et al. 2004, Ireland 1987, Suguio et al. 1985, Ybert et al. 2003), and reaching one or two meters below the actual sea level. From this time at today, the bay started to be fulfilled with sediments, when the sea level got higher and was maintained, with few intermediary oscillations, just the actual size of the bay. Mangroves were installed out of the deep waters. The question now is, how old are the mangroves that persist just today.

A drilling core, $133 \mathrm{~cm}$ long, was obtained in the Guapimirim mangrove, at $22^{\circ} 41,10^{\prime} \mathrm{S}$ and $43^{\circ} 04,79^{\prime} \mathrm{W}$, by the team of the LAGEMAR (Laboratório de Geologia Marinha, Departamento de Geologia, Universidade Federal Fluminense), and was coordinated by Dr. J.A. Baptista-Neto. The bottom of this muddy core reached a sandy ground.

The sediment of the core level corresponding to $122 \mathrm{~cm}$ from the top was dated by Beta Analytic Inc. The age comprised $1760 \pm 50$ years B.P.

The palynological analysis of the sediment of this core level was realized following the proposed standard methodology (Ybert et al. 1992). The most frequent pollen grains belonged to the mangrove species Rhizophora mangle (2.6\%), Laguncularia racemosa $(1.3 \%)$ and Avicennia schaueriana $(2.6 \%)$. Pollen grains of Arecaceae (11.3\%), Solanaceae (33.5\%), Alchornea (12.9\%), Schinus (2.3\%) and Trichilia (3.2\%) occurred also, representing both the "restinga" and the tropical rain forest. Pollen and spore preservation was excellent, except some pollen grains of Alchornea that suffered long distance transport. Pteridophyta spores $(24.2 \%)$ were not frequent in the sediment of this core level, indicating that they were not abundant in this area, and were proceeding from more distant places.

At the time of this sediment deposition, according to the pollen and spore spectrum, the seawater had fulfilled the bay into its actual size, since the last transgression at circa 2500 years B.P. (Suguio et al. 1985), allowing the installation of the mangrove.

The palynological analysis of more or less 6000 years old sediments of two cores obtained in the Bay of Sepetiba, southern region of the state of Rio de Janeiro (Coelho et al. 2002, Santos et al. 2000), revealed that mangroves prevailed in the study area all over this time. These cores were more than $5 \mathrm{~m}$ long, and presented a strong lithological alteration just in the level corresponding to 1700 years B.P., when mangrove pollen grain concentration decreased. A possible sea level change may be responsible for this 
fact, at the same time when the Guapimirim mangrove was installed.

In conclusion, at the age of 1760 years B.P., the mangrove has been installed, receiving sediments including pollen and spores from rivers coming from the surrounding plains and the mountains around the Guanabara region.

No human activities, at this time, could be detected by pollen analysis.

\section{ACKNOWLEDGMENTS}

To Dr. José Antônio Baptista Neto, Laboratório de Geologia Marinha (LAGEMAR), Departamento de Geologia, Universidade Federal Fluminense and Dr. Claudia Gutterres Vilela, Departamento de Geologia, Universidade Federal do Rio de Janeiro, for core sample supply. Financial support: Conselho Nacional de Desenvolvimento Científico e Tecnológico (CNPq) and Fundação Carlos Chagas Filho de Amparo à Pesquisa do Estado do Rio de Janeiro (FAPERJ).

\section{RESUMO}

Uma amostra de sedimento foi obtida a $122 \mathrm{~cm}$ de profundidade a partir do topo de um testemunho no manguezal de Guapimirim, Baía de Guanabara, e avaliada por análise palinológica. A base deste testemunho lamoso de $133 \mathrm{~cm}$ atingiu um depósito arenoso. A datação por ${ }^{14} \mathrm{C}$ obteve a idade de $1760 \pm 50$ anos A.P. Os grãos de pólen mais frequientes eram das espécies de manguezais Rhizophora mangle, Laguncularia racemosa e Avicennia schaueriana. A vegetação de restinga e de mata pluvial tropical foi localizada atrás do manguezal. Após a última transgressão marinha, cerca de 2500 anos A.P., o nível de água da baía baixou até sua altura atual possibilitando a instalação deste manguezal.

Palavras-chave: pólen, paleoambiente, manguezal, Baía de Guanabara, Rio de Janeiro, 1760 A.P.

\section{REFERENCES}

AMAdOR ES. 1997. Baía de Guanabara e Ecossistemas Periféricos: Homem e Natureza. Edição do Autor, Rio de Janeiro, RJ, Brasil, 539 p.
Barth OM, Barreto CF, Coelho LG And Luz CFP. 2004. Pollen record and paleoenvironment of a 4210 years B.P. old sediment in the Bay of Guanabara, Rio de Janeiro, Brazil. An Acad Bras Cienc 76: 549-551.

Coelho LG, BARth OM AND Chaves HAF. 2002. Palynological records of environmental changes in Guaratiba mangrove área, southeast Brazil, in the last 6000 years B.P. Pesquisas em Geociências 29: 71-79.

IRELAND S. 1987. The Holocene sedimentary history of the coastal lagoons of Rio de Janeiro state, Brazil. In: Tooley MJ And Shennan I (Eds), Sea level changes. Basil Blackwell. The Institute of British Geographers Special Publications Series: 26-66. (in MueHe D AND KNeIP L 1995. O sambaqui de Camboinhas e o de Maratuá e as oscilações relativas do nível do mar. Documento de Trabalho. Série Arqueologia, Museu Nacional, UFRJ, Rio de Janeiro, RJ, Brasil 3: 75-82.

KNEIP L. 2001. O sambaqui de Manitiba I e outros sambaquis de Saquarema, RJ. Documento de Trabalho. Série Arqueologia, Museu Nacional, UFRJ, Rio de Janeiro, RJ, Brasil 5: 91.

SAntos DS, BARTh OM AND Chaves HAF. 2000. Mudanças na vegetação do manguezal de Guaratiba, estado do Rio de Janeiro, nos últimos 6.000 anos, baseado em Palinologia. Revista Universidade Guarulhos, Geociências V (número especial): 156-159.

Suguio K, MARTin L, BitTencourt ACSP, Dominguez JML, FleXor JM AND AZEVEdo AEG. 1985. Flutuações do nível relativo do mar durante o Quaternário Superior ao longo do litoral brasileiro e suas implicações na sedimentação costeira. Rev Bras Geocienc 15: 273-286.

Ybert JP, SALGado-Labouriau ML, BARTh OM, Lorscheiter ML, BARros MA, ChaVES SAM, LuZ CFP, RibEIRo M, SCHEEL R AND VicENTINI K. 1992. Sugestões para padronização da metodologia empregada em estudos palinológicos do Quaternário. Rev Inst Geol São Paulo 13: 47-49.

YBERT JP, Bissa WM, CATHARINO ELM AND KUTNER M. 2003. Environmental and sea-level variations on the southeastern Brazilian coast during the Late Holocene with comments on prehisoric human occupation. Palaeogeogr Palaeoclimatol Palaeoecol 189: 11-24. 